\title{
CAREER AFTER RETIREMENT: A COMPARISON BETWEEN FORMER FEMALE AND MALE ATHLETES IN HOCHIMINH CITY - VIETNAM
}

\section{Nguyen Hoang Minh Thuan*}

\author{
University of Sport Ho Chi Minh City
}

DOI: https://doi.org/10.15520/ijmhs.v9i12.2752

Reviewed By: Dr.

Daniel V.

Department: Medical

\section{ABSTRACT}

The results showed that most athletes retire for reasons such as: anxiety for future careers, no achievements, injuries.... After retirement, they receive the assistance form many individuals and organizations. Many former male athlete work in sport field, their income is also better former female athlete; Although income is the most common trait that former female athletes choose to work. Keywords: Difference, former athlete, career, retirement

* Corresponding author.

Email:

thuantt2@gmail.com.

\section{INTRODUCTION}

The career transition process and career after retirement of athletes, especially high performance sports, is a matter of special social and scientific interest. It began to be widely studied after the 1970s. The results mostly acknowledge difficulties when start another job after retirement. In particular, the reasons for retirement or the difficulties of male and female athletes are not the same. In fact, even before retiring, their operating conditions also had significant differences.
According to a 2014 study by the Center Women in Sports at the University of Minnesota (USA). Only a maximum of $4 \%$ of information on women's sports is reported by the media, while up to $40 \%$ of sports activities are for women [5].

A report by Women on Boards presents a problem in many industries, with less than $30 \%$ of executive board positions being owned by women.

Women accounted for only $18 \%$ of all executive members of the 28th International Sports 
Federation participating in the survey. Of the 129 National Olympic Committees, the figures were even lower and even tended to decrease - women accounted for $16.6 \%$ of the executive committee, down from $17.6 \%$ in 2014 [5].

In fact, the gender pay gap spans almost every industry, and sports is no different. But between particular sports, there are vast discrepancies in pay for men and women, ranging from tennis, where pay is comparable, to basketball, where players are in entirely different zip codes [2].

In Vietnam, that is no different. There is a significant gender difference in the field of sports. And up to now this issue has not really been adequately addressed. I hope this study will find out specific differences in career transition or choise career of former athletes by gender. Thereby to get the attention, proper investment for the work, the life of the athlete after retirement is better developed in the future.

\section{METHODOLOGY}

The questionnaire of the study is referenced mainly from of Zhijian Huang's research in 2002 [4]. Due to the time gap and cultural differences between the two countries, the author has adjusted accordingly better suited to the current time and Vietnamese culture.

Questionnaire include both qualitative and quantitative questions. The quantitative answers are often more simple to answer and analyses but in the other hand the qualitative answers provide more detailed information and allow the athletic to present their opinions.

Through the help of more than 80 volunteers who have been thoroughly trained, the interview was done by face to face, it includes 2 part: talking to former athletes (about health, life, spirit) .and help them complete the interview form.

The total number of form we prepared was 600 . However, there are still many cases of refuse this interview or fails to comply (ineligible) and we respect them. The actual sample of the research was 400 and the number of responses was 318 .

This response rate is higher than the study of Else Suutarinen in 2014. This difference is very large and explained by this study to choose faceto-face interviews instead of sending letters in the form of an email.

The research process uses the following methods: reading, analyzing and synthesizing documents; Sociological survey and statistical mathematics on SPSS 22.0 software.

\section{RESULTS AND DICUSTION}

\subsection{The difficulties of former athletes in the career transitions}

\section{Reason for retirement}

Worrying about future careers is the main reason affecting athletes' retirement. t-test results show that there is no difference between male and female in the reasons of the former athletes' retirement, Sig. $=.776(>.05)$.

Table 2.1: Reason for retirement of former athletes

Unit: \%

\begin{tabular}{cccccccc}
\hline & \multicolumn{9}{c}{ Reason } & & t-test \\
\cline { 2 - 5 } \cline { 5 - 7 } Gender & Injury & Personal & Future careers & No achievements & Other & & $\begin{array}{c}\text { Total } \\
\text { (2-tailed) }\end{array}$ \\
\hline Male & 11.9 & 31.3 & 35.8 & 10.4 & 10.4 & 100 & .776 \\
Female & 10.3 & 31.9 & 37.9 & 15.5 & 4.3 & 100 & .776 \\
\hline
\end{tabular}


Psychological status after the end of a sports career

After the end of the sports career, most former athletes fell into a state of depression. The number of female athletes in a very depressed state is higher than that of men. However, this result is not statistically significant, Sig. $=.955$ $(>.05)$.

Table 2.2: Psychological status after the end of a sports career

\begin{tabular}{|c|c|c|c|c|c|c|}
\hline \multirow[b]{2}{*}{ Gender } & \multicolumn{4}{|c|}{ Status } & \multirow[b]{2}{*}{ Total } & \multirow{2}{*}{$\begin{array}{c}\text { t-test } \\
\text { Sig. } \\
\text { (2-tailed) }\end{array}$} \\
\hline & Very depression & Depression & Comfortable & Very comfortable & & \\
\hline Male & 8.9 & 59.7 & 19.4 & 11.9 & 100 & 055 \\
\hline Female & 10.3 & 58.6 & 18.1 & 12.9 & 100 & \\
\hline
\end{tabular}

However, their perceptions of the attitude of social relationships when they retire are positive. In particular, the majority of former male and female athletes still feel treated normally, even empathy, sharing. The number of people feeling frustrated by this is $9 \%$ for men and $7.8 \%$ for women.

\section{Assistance during athletic career transition process.}

After retirement, most athletes receive the help of many individuals and organizations. The overall results also indicate that female athletes often receive more support than male athletes. In which the Sports Association (SA) is the most supportive. Male athletes receive the most help from sports clubs.

Table 2.3: Assistance during athletic career transition process.

\begin{tabular}{cccccccc}
\hline & \multicolumn{1}{c}{} & & & & Unit: $\%$ \\
\hline Gender & Coach & Club & SA & Career advice & Family & Friend & Other \\
\hline Male & 8 & 24 & 21 & 7 & 7 & 18 & 29 \\
\hline Female & 12 & 37 & 44 & 18 & 5 & 41 & 47 \\
\hline
\end{tabular}

\subsection{Differences between former male and female athletes for choice career}

\section{The adjustment process of life}

The account of time necessary to adjust to a post-athletic career after sport career end was also investigated. The result can be seen in table table. It reveals that almost half of the former athletes acclimatize to a new career and environment in one to two years.
$23.9 \%$ male needed more than two years to get over this process. $20.9 \%$ needed one year to balance. $7.5 \%$ former athletes adapted to new situation within one month.

Similar to male, $29.3 \%$ female needed more than two years to get over this process. $22.4 \%$ needed one year to balance. $2.6 \%$ former female athletes adapted to new situation within one month. However, no difference between sex groups, sig. $=.125(>.05)$. 
These results indicate that there are remarkable individual differences among retired elite athletes in the re-adaptation to former athletic life environment. Some of these athletes went through it smoothly, while others could hardly accomplish this process even after more than two years.

\section{Tablel 2.4: The adjustment process of life}

Unit \%

\begin{tabular}{|c|c|c|c|c|c|c|c|c|}
\hline \multirow[b]{2}{*}{ Gender } & \multicolumn{6}{|c|}{ Time } & \multicolumn{2}{|r|}{ t-test } \\
\hline & More than 2 years & One - two year & One year & Half a year & One month & Khác & Total & $\begin{array}{c}\text { Sig. } \\
\text { (2-tailed) }\end{array}$ \\
\hline Male & 23.9 & 28.4 & 20.9 & 17.9 & 7.5 & 1.5 & 100 & \\
\hline Female & 29.3 & 31.9 & 22.4 & 12.1 & 2.6 & 1.7 & 100 & (12) \\
\hline
\end{tabular}

\section{Characteristics to choose career}

The results of the t-test showed that there was no statistically significant difference in the current job selection characteristics of former athletes.
The former male athletes choose the current job because their passion is the highest $(40.3 \%)$, the former female athlete chooses the job that is mainly concerned with the income $(26.7 \%)$.

\section{Table 2.5: Characteristics to choose career}

\begin{tabular}{|c|c|c|c|c|c|c|c|c|}
\hline \multirow[b]{2}{*}{ Gender } & \multicolumn{6}{|c|}{ Characteristics } & \multirow[b]{2}{*}{ Total } & \multirow{2}{*}{$\begin{array}{c}\text { t-test } \\
\text { Sig. } \\
\text { (2-tailed) }\end{array}$} \\
\hline & Accordingly & Income & Opportunity & Passion & Environment & Other & & \\
\hline Male & 14.9 & 23.9 & 6.0 & 40.3 & 13.4 & 1.5 & 100 & 251 \\
\hline Female & 12.1 & 29.3 & 6.0 & 19.0 & 26.7 & 6.9 & 100 & IJנ. \\
\hline
\end{tabular}

\section{Career fields}

The study is also interested in current career fields. The current career fields of former athletes, many the former male athletes work in the field of sports and trading (37.3\%). The lowest is the field of design consultancy and information technology (IT). While, the trading was chosen by the former female athlete with the highest rate, the lowest was design and health consulting $(0.9 \%)$.

This choice did not have a significant difference.

\section{Table 2.6: Career fields}

Unit: \%

\begin{tabular}{|c|c|c|c|c|c|c|c|c|c|c|c|}
\hline \multirow[b]{2}{*}{ Gender } & \multicolumn{7}{|c|}{ Career fields } & \multirow[b]{2}{*}{ Education } & \multirow[b]{2}{*}{ Travel } & \multirow[b]{2}{*}{ Total } & \multirow{2}{*}{$\begin{array}{c}\text { t-test } \\
\text { Sig. } \\
\text { (2-tailed) }\end{array}$} \\
\hline & Sport & Design & Trading & Health & Sevice & Producetion & IT & & & & \\
\hline Male & 37.3 & 1.5 & 37.3 & 0.0 & 11.9 & 3.0 & 1.5 & 7.5 & 0.0 & 100 & \\
\hline Female & 30.2 & 0.9 & 37.1 & 0.9 & 3.4 & 8.6 & 0.9 & 16.4 & 1.7 & 100 & סוט. \\
\hline
\end{tabular}




\section{Income}

The results of the t-test showed that there was no difference in the income of former male and female athletes, sig. $=.277(>0.5)$. However, the majority of former male athletes earn more than 431.68 USD (46.3\%). Former female athletes have a main income from 215,91 to less than 345.47 USD (39.7\%).

Table 2.7: Income form current job

\begin{tabular}{|c|c|c|c|c|c|c|}
\hline \multirow{2}{*}{ Gender } & \multicolumn{4}{|c|}{ Income (USD) } & \multicolumn{2}{|r|}{ T-test } \\
\hline & Below 215,91 & 215,91-below 345,47 & 345,47-below 431.68 & Over 431.68 & & (2-tailed) \\
\hline Male & 16.4 & 14.9 & 22.4 & 46.3 & 100 & 277 \\
\hline Female & 13.8 & 39.7 & 8.6 & 30.2 & 100 & (2) \\
\hline
\end{tabular}

\section{The degree of cohesion with the work}

There is statistically significant difference in the degree of cohesion with the work between male and female groups. The former athletes signed a long-term contract with the work is highest proportion $(35.8 \%)$, short-term is $26.9 \%$, free is $14.9 \%$ and public servant are $17.9 \%$

While, former female athletes prefer freedom (accounting for $30.2 \%$ ), short-term is $27.6 \%$, Public servant is $14.7 \%$.

Table 2.8: The degree of cohesion with the work

Unit: \%

\begin{tabular}{|c|c|c|c|c|c|c|c|c|}
\hline \multirow[b]{2}{*}{ Gender } & \multicolumn{6}{|c|}{ Cohesion } & \multirow[b]{2}{*}{ Total } & \multirow{2}{*}{$\begin{array}{c}\text { t-test } \\
\text { Sig. } \\
\text { (2-tailed) }\end{array}$} \\
\hline & $\begin{array}{l}\text { Public } \\
\text { servant }\end{array}$ & Long term & Short term & Collaborator & $\begin{array}{l}\text { Do not } \\
\text { want }\end{array}$ & Free & & \\
\hline Male & 17.9 & 35.8 & 26.9 & 4.5 & 0.0 & 14.9 & 100 & \multirow{2}{*}{.001} \\
\hline Female & 14.7 & 12.9 & 27.6 & 6.0 & 8.6 & 30.2 & 100 & \\
\hline
\end{tabular}

\section{CONCLUSIONS}

In general, most athletes retire for reasons such as: anxiety for future careers, no achievements, injuries ... with feelings of depression. This period female athletes often receive support more than male athletes. While, the Sports Association is the most supportive. Male athletes receive the most help from sports clubs. The time to adjust the life after retirement between male and female athletes was not same, but there was no statistically significant difference.

Former male athlete work in sport fiel higher than former female athletes. In general, their income is better (over 431,68 USD/month) compared to female (from 215,91 - 345,47 $\mathrm{USD} / \mathrm{month})$. However, in fact, the former male athletes choose the current job because their passion is the highest; the former female athlete chooses the job that is mainly concerned with income. There is statistically significant difference in the degree of cohesion with the work between male and female.

\section{REFERENCES}

1. Else Suutarinen (2014), Employment of the professional athletes after retirement - Case Athlete Career Programme in Finland, pp. 26-29. 
2. Olivia Abrams (2019), Why Female Athletes Earn Less Than Men Across Most Sports.

3. Vickers, E., 2013. Life After Sport: Depression in the Retired Athlete, In: The Sport in Mind.

4. Zhijian Huang, 2002, Athletic career transition in former Chinese elite athletes: an empirical investigation and cross-cultural comparison with findings from Germany, pp 90-109.

5. Web:

https://www.bbc.com/vietnamese/sport41722495 